\title{
GAYA BELAJAR DAN METODE MENGAJAR DOSEN AKUNTANSI
}

\author{
Sri Pujiningsih \\ Universitas Negeri Malang \\ sri.pujiningsih.fe.@um.ac.id
}

\begin{abstract}
The objectives of this research are to describe learning style and instructional method of accounting lecturers. The subjects of the research are 22 accounting lecturers. Data analysis uses descriptive analysis. Results of the research conclude major of the accounting lecturers have accommodator style. Their learning style influence their instructional method. They prefer give more individual and group assignments.
\end{abstract}

Key words: learning style, instructional method.

Abstrak: Penelitian ini bertujuan untuk mendeskripsikan gaya belajar dan metode mengajar dosen akuntansi. Subjek dari penelitian ini adalah 22 Dosen Akuntansi. Analisis data penelitian menggunakan teknik analisis deskriptif. Hasil penelitian menyimpulkan bahwa sebagian besar Dosen Akuntansi bergaya belajar accommodator. Gaya belajar ini merupakan perpaduan antara concentrate experience dan active experimentation. Gaya belajar ini berpengaruh terhadap metode mengajar dosen. Mereka lebih menyukai pemberian banyak tugas individu maupun kelompok.

Kata Kunci: gaya belajar, metode mengajar.

Penelitian Duff (1995) menyimpulkan bahwa mahasiswa akuntansi lebih suka menggunakan pembelajaran teoritikal. Pujiningsih (2010) menjelaskan bahwa mahasiswa akuntansi cenderung lebih suka dosen yang menjelaskan materi secara rinci atau bergaya dependen. Adel at al. (2003), menyimpulkan sebagian besar mahasiswa akuntansi memiliki gaya belajar converger, yakni gaya belajar dengan cara memikirkannya (Abstract Conceptualization/AC) serta memproses informasi yang diperoleh dengan cara mempraktikannya (active experimentation/AE). Beberapa penelitian tersebut menghasilkan kesimpulan yang berbeda.

Salah satu model gaya belajar dikembangkan oleh Kolb (Pujiningsih, 2010). Gaya belajar ini dilihat dari dimensi perceiving information dan processing information. Kolb (1985) telah mengembangkan instrumen yang disebut Learning Style Inventory (LSI). Kolb membagi empat jenis gaya belajar, yakni accomodator, diverger, assimilator dan converger (Pujiningsih, 2010). Gaya belajar accomodator adalah gaya belajar seseorang 
yang lebih menyukai pengalaman (concentrate experience) dan aktif bereksperimen (active experimentation). Gaya belajar diverger adalah gaya belajar seseorang yang lebih menyukai pengalaman (concentrate experiencing) dan mengamati (reflective observation). Gaya belajar converger adalah gaya belajar seseorang yang lebih menyukai sesuatu yang abstrak (abstract conceptualization) dan aktive bereksperimen (active experimentation). gaya belajar assimilator adalah gaya belajar seseorang yang lebih menyukai pada sesuatu yang abstrak (abstract conceptualization) dan mengamati (reflective observation).

Anderson (1985) menyatakan bahwa perbedaan hasil pembelajaran disebabkan oleh perbedaan metode instruksional dan proses informasi. Pemrosesan informasi adalah salah satu komponen dalam gaya belajar (Adel et al., 2003). Dengan demikian, metode instruksional dan gaya belajar dosen akan berpengaruh terhadap hasil pembelajaran mahasiswa. Mahasiswa dengan gaya belajar yang mirip dosen pengampu mata kuliah tertentu, cenderung memiliki kinerja yang lebih baik atau lebih tinggi tingkat kepuasannya (Gaiger and Boyle,1992). Bagaimanakah gaya belajar Dosen Akuntansi? apakah gaya belajar Dosen akuntansi berpengaruh terhadap metode instruksionalnya?

Bonner (1999) menjelaskan beberapa metode instruksional yang dilakukan dosen antara lain: membaca buku teks, memberikan contoh kasus atau memberi pertanyaan objektif, mendengarkan dosen, melihat video yang ditayangkan, melihat peragaan; mendengarkan dan berpartisipasi aktif dalam proses perkuliahan, menjawab pertanyaan singkat, menulis dan menjawab pertanyaan, mengerjakan tugas dalam bentuk kasus singkat, mengerjakan tugas tidak terstruktur dalam bentuk kasus, mendiskusikan topik tertentu dengan teman lain, melakukan penelitian; melakukan presentasi dan menjawab pertanyaan, partisipasi dalam demonstrasi seperti bermain peran, siulasi, dan eksperimen. Bagimanakah metode mengajar dosen Akuntansi?

Berangkat dari pertanyaan mengenai gaya belajar dosen akuntansi, maka motivasi dari penelitian ini adalah ingin mengetahui apakah gaya belajar dosen akuntansi sama dengan gaya belajar mahasiswa akuntansi. Hal ini untuk mengonfirmasi hasil penelitian Gaiger and Boyle (1992) bahwa gaya belajar mahasiswa yang mirip dosen cenderung memiliki kinerja atau hasil belajar yang lebih baik. Kebiasaan bekerja mahasiswa seperti menyelesaikan tugas berhubungan dengan keberhasilan mahasiswa (Fad and Ryser, 
1993). Penyelesaian tugas perkuliahan yang dilakukan mahasiswa sangat berkaitan dengan metode mengajar dosen. Dengan demikian, motivasi lain dari penelitian ini adalah untuk mengetahui metode mengajar dosen yang dipengaruhi oleh gaya belajarnya.

\section{METODE}

Penelitian ini merupakan penelitian deskriptif. Penelitian deskriptif dilakukan $\mathrm{n}$ terhadap masalah-masalah berupa fakta-fakta saat ini dari suatu populasi. Jenis penelitian deskriptif umumnya berkaitan dengan opini (individu, kelompok atau organisasional) kejadian atau prosedur (Indriantoro dan Supomo,1999). Dalam konteks penelitian ini metode mengajar adalah opini dosen akuntansi terhadap metode pengajaran yang digunakannya dalam proses pembelajaran. Sementara gaya belajar adalah cara belajar atau kondisi belajar yang disukai oleh mahasiswa. Penelitian ini merupakan penelitian populasi. Adapun subyek dalam penelitian adalah seluruh dosen Jurusan Akuntansi Fakultas Ekonomi Universitas X. Teknik pengumpulan data dari subyek yang diteliti (responden) dengan menggunakan angket. Angket dikembangkan berdasarkan pada instrumen yang telah dikembangkan oleh Kolb untuk gaya belajar (Pujiningsih, 2010) dan Richio and Sakata (2000) untuk metode mengajar. Masing-masing instrumen telah diuji tingkat validitas dan reliabilitas. Metode analisis data yang digunakan dalam penelitian ini adalah analisis deskriptif.

\section{HASIL}

Jumlah dosen jurusan akuntansi fakultas X sebanyak 27 orang. Dosen yang berpartisipasi mengisi angket sebanyak 23 atau sebanyak $79 \%$. Dari 23 eksemplar tersebut terdapat satu eksemplar yang tidak diisi secara lengkap oleh responden, sehingga tidak dimasukkan dalam analisis data. Dengan demikian, hanya 22 angket yang dapat dianalisis. Dari 22 responden tersebut 5 orang dosen berjenis kelamin laki-laki dan sisanya berjenis kelamin perempuan.

\section{Gaya Belajar Dosen Akuntansi}


Berikut ini disajikan data mengenai preferensi gaya belajar dosen akuntansi ditinjau dari perceiving information, processing information dan preferensi gaya belajar menurut teori Kolb (Pujiningsih, 2010).

Tabel 1. Preferensi Gaya Belajar Dosen Akuntansi

\begin{tabular}{|c|c|}
\hline \multicolumn{2}{|c|}{ Perceiving Information } \\
\hline Abstract Conceptualization (AC) & $19 \%$ (4 orang) \\
\hline Concentrete Expereince (CE) & $81 \%$ (18 orang) \\
\hline Total & 100 (22 orang ) \\
\hline \multicolumn{2}{|c|}{ Processing Information } \\
\hline Reflective Observation (RO) & $29 \%$ (5 orang) \\
\hline Active Experimentation (AE) & $71 \%$ (17 orang) \\
\hline Total & $100 \%(22$ orang) \\
\hline & Preferensi Gaya Belajar \\
\hline Accomodator/Activist & $38 \%(8)$ \\
\hline Converger/pragmatis & $23 \%(5)$ \\
\hline Diverger/Refflector & $27 \%(6)$ \\
\hline Assimilator/Theorist & $12 \%(3)$ \\
\hline Total & $100 \%(22$ orang) \\
\hline
\end{tabular}

Sumber : data diolah

\section{Perceiving Information}

Berdasarkan data yang disajikan dalam tabel 1, ditinjau dari cara dosen akuntansi mendapatkan informasi atau perceiving information, sebanyak $0,81 \%$ atau 18 orang dosen lebih menyukai cara mendapatkan informasi berdasarkan pada pengalaman atau Concentrete Experience (CE), sedangkan sisanya sebanyak 19\% atau 4 orang dapat yang lebih menyukai dengan cara berfikir abstrak atau Abstract Conceptualization (AC). Dengan demikian dapat disimpulkan bahwa sebagian besar dosen akuntansi dalam menerima informasi lebih banyak berdasarkan pengalaman daripada berdasarkan berfikir abstrak. Hasil ini menjelaskan bahwa Dosen Akuntansi lebih menyukai sebuah ide yang empiris, Dosen Akuntansi lebih suka menjelaskan dengan fakta dan kontekstual, Dosen akuntansi lebih mudah mengingat sesuatu apabila hal tersebut pernah dilakukan, dan Dosen Akuntansi lebih mudah memahami sesuatu yang baru dengan cara mempraktikannya.

\section{Information Processing Mode}

Berdasarkan pada data yang terdapat pada Tabel 1, ditinjau dari cara dosen akuntansi dalam memproses informasi atau information processing, sebanyak $0,71 \%$ atau 
17 orang lebih menyukai memproses informasi dengan cara active experimentation (AE) yakni memproses informasi dengan cara melakukannya, sedangkan sisanya sebesar 0,29\% atau 5 orang lebih menyukai dengan cara Reflective Observation (RO) yakni memproses informasi dengan cara mengamati obyek. Dengan demikian dapat disimpulkan bahwa dalam memroses informasi baru, dosen akuntansi lebih menyukai dengan cara melakukan eksperimen atau mencoba melakukannya dibandingkan dengan cara mengamatinya. Hasil ini menjelaskan bahwa dosen akuntansi dalam memberi pemahaman kepada mahasiswa, antara lain dilakukan dengan memberikan latihan soal dan penyelesaian kasus.

\section{Learning style}

Berdasarkan pada gaya belajar yang dikembangkan oleh Kolb, preferensi gaya belajar dapat dibedakan kedalam empat jenis yakni accomodator/ activist, diverger/refflector, converger/pragmatis, dan Assimilator/Theorist. Berdasarkan pada data yang yang disajikan pada Tabel 1, dosen akuntansi paling banyak menyukai gaya belajar accomodator, yakni sebanyak $0,38 \%$ atau 8 orang. Sisanya $0,27 \%$ atau 6 orang bergaya diverger, $0,23 \%$ atau 5 orang bergaya converger, dan $0,12 \%$ atau 3 orang bergaya assimilator. Gaya belajar accomodator adalah gaya belajar seseorang yang lebih menyukai pengalaman (concentrate experience) dan aktif bereksperimen (active experimentation). Dengan kata lain, dosen Akuntansi lebih menyukai mendapatkan informasi berdasarkan pengalaman dan memrosesnya dengan cara memraktikkan atau melakukannya. Sedangkan paling sedikit atau 3 orang dosen menyukai gaya belajar assimilator, gaya ini adalah gaya seseorang dalam mendapatkan informasi dengan cara memikirkannya serta memroses onformasi tersebut dengan cara mengamati obyek pembelajaran.

\section{Metode Pembelajaran}

Menurut Reigeluth (Dwiyogo, 2004), metode pembelajaran termasuk bagian dari variabel pembelajaran. Metode pembelajaran dalam penelitian ini meliputi pengelolaan kelas dan metode mengajar. 


\section{Pengelolaan Kelas}

Berikut ini adalah data mengenai opini Dosen Akuntansi mengenai pengelolaan

kelas selama proses pembelajaran. Skor terhadap masing masing pernyataan apabila Sangat Setuju (SS) dengan skor 5; Setuju (S) dengan skor 4; Cukup Setuju (CS) dengan Skor 3 ; Tidak Setuju (TS) dengan skor 2 dan Sangat Tidak Setuju (STS) dengan skor 1.

Tabel 2. Pengelolaan Kelas

\begin{tabular}{|c|c|}
\hline Pernyataan & $\begin{array}{l}\text { Rata-rata } \\
\text { Nilai }\end{array}$ \\
\hline a. $\quad$ Tata tertib untuk mahasiswa adalah hal yang penting & 4,77 \\
\hline $\begin{array}{l}\text { b. Pengumpulan tugas oleh mahasiswa secara tepat waktu adalah penting } \\
\text { dan harus dihormati. }\end{array}$ & 4,63 \\
\hline $\begin{array}{l}\text { c. Saya selalu memberikan poin tersendiri bagi mahasiswa yang suka } \\
\text { bertanya pada saat perkuliahan }\end{array}$ & 4,72 \\
\hline $\begin{array}{llllll}\text { d. Saya selalu memperhatikan apa yang mahasiswa pelajari dan } \\
\text { bagaimana mereka belajar }\end{array}$ & 4,31 \\
\hline $\begin{array}{l}\text { e. Saya sangat memperhatikan masukan atau umpan balik dari mahasiswa } \\
\text { mengenai kinerja saya dalam mengajar. }\end{array}$ & 4,63 \\
\hline $\begin{array}{l}\text { f. Saya mencoba memberikan perhatian lebih terhadap mahasiswa yang } \\
\text { kurang respon terhadap proses pembelajaran. }\end{array}$ & 3,63 \\
\hline
\end{tabular}

Sumber: Data diolah

Berdasarkan pada tabel 2 tersebut di atas, dapat disimpulkan bahwa sebagian besar responden sangat setuju menekakankan disiplin dan tata tertib bagi mahasiswa, dengan skor rata-rata sebesar 4,77. Sedangkan nilai rata-rata terendah terdapat pada pernyataan dosen mencoba memberikan perhatian yang lebih terhadap mahasiswa yang kurang respon terhadap proses pembelajaran, yakni sebesar3,63.

\section{Metode Mengajar}

Berikut adalah data mengenai metode mengajar yang digunakan oleh Dosen Akuntansi selama proses pembelajaran.

Tabel 2. Metode Mengajar

\begin{tabular}{|l|c|}
\hline \multicolumn{1}{|c|}{ Metode Mengajar } & Persentase (\%) \\
\hline a. ceramah & $21 \%$ \\
\hline b. penugasan kelompok di kelas & $15 \%$ \\
\hline c. penugasan kelompok di luar kelas & $13 \%$ \\
\hline d. penugasan penyelesaian kasus & $14 \%$ \\
\hline e. penugasan rumah secara individual & $17 \%$ \\
\hline f. penelitian pustaka & $5 \%$ \\
\hline g. seminar & $2 \%$ \\
\hline h. penelitian dengan fasilitas internet & $7 \%$ \\
\hline
\end{tabular}


i. kunjungan ke perusahaan

$6 \%$

Sumber: Data diolah

Berdasarkan pada tabel 2 di atas, dapat disimpulkan bahwa metode ceramah atau traditional lecture masih banyak digunakan sebagian besar responden yakni sebesar $21 \%$, sedangkan urutan kedua metode pengajaran yang banyak digunakan adalah penugasan rumah secara individual sebanyak 17\%. Metode pengajaran yang paling sedikit dilakukan adalah seminar sebanyak $2 \%$.

Tabel 3 menunjukkan opini responden mengenai metode mengajar yang selama ini mereka gunakan.

Tabel 3. Opini Metode Mengajar

\begin{tabular}{|l|c|}
\hline \multicolumn{1}{|c|}{ Opini } & Persentase \\
\hline a. Ingin mengubah tetapi tidak tahu bagaimana melakukannya & $0 \%$ \\
\hline b. Ingin mengubah tetapi tidak memiliki sumber untuk melakukannya & $5 \%$ \\
\hline $\begin{array}{l}\text { c. Ingin mengubah tetapi tidak punya cukup waktu untuk } \\
\text { melakukannya }\end{array}$ & $41 \%$ \\
\hline d. Tidak ingin mengubah & $14 \%$ \\
\hline e. Lainnya ... & $41 \%$ \\
\hline
\end{tabular}

Sumber: Data diolah

Berdasarkan pada tabel 3 di atas, sebanyak $41 \%$ atau 9 orang dosen ingin mengubah metode yang selama ini digunakan tetapi mereka tidak memiliki cukup waktu. Sedangkan $41 \%$ atau 9 orang lainnya menjawab dengan pertanyaan terbuka bahwa mereka dalam metode pengajarannya menyesuaikan dengan kondisi kelas, ada sebagian yang selalu memperbarui metodenya, ada yang tidak mengubah metode mengajarnya tetapi selalu memperbarui materi, ada yang mengubah metode sesuai materi yang disampaikan. Sedangkan sebanyak 0,14 atau 3 orang dosen tidak ingin mengubah metode pengajaran yang selama ini digunakannya.

\section{PEMBAHASAN}

Pembahasan dalam tulisan ini dikelompokkan menjadi dua yaitu gaya mengajar dan metode mengajar.

\section{Gaya Belajar}


Berdasarkan pada analisis data yang telah dilakukan, bahwa sebagian besar dosen akuntansi dalam mendapatkan informasi, lebih menyukai berdasarkan pengalaman atau concentrete experience, yakni sebesar $0,81 \%$ atau 18 orang dibandingkan dengan cara memikirkannya atau abstract conceptualization (AC). Hasil penelitian ini berbeda dengan penelitian yang telah dilakukan oleh Adel, at al. (2003). Berdasarkan penelitian Adel et al., (2003), sebagian besar mahasiswa akuntansi lebih menyukai mendapatkan informasi dengan cara abstract conceptualization (AC) yakni sebanyak 86\%.

Dalam hal memproses informasi yang telah diterimanya, sebagian besar dosen lebih menyukai cara belajar yang active experimentation (AE) yakni sebesar $0,71 \%$ atau 17 orang. Hasil penelitian ini konsisten dengan penelitian yang telah dilakukan oleh Adel at al. (2003), sebanyak 54\% mahasiswa akuntansi lebih menyukai dengan cara active experimentation (AE).

Preferensi gaya belajar menurut Teori Kolb (1985), Dosen Akuntansi sebagian besar memiliki gaya belajar accomodator, yakni sebanyak 0,38\% atau 8 orang. Gaya belajar ini merupakan perpaduan gaya belajar antara perceiving information secara concentrate experience (CE) dan processing information secara Active Experiments (AE). Dengan kata lain, gaya belajar ini menunjukkan kecenderungan seseorang dalam belajarnya lebih menyukai pengalaman dan aktif mempraktikkannya. Gaya ini terefleksikan dalam metode mengajar Dosen Akuntansi dengan cara penugasan kelompok di kelas (15\%), penugasan kelompok di luar kelas (13\%), penyelesaian kasus (14\%), dan penugasan di rumah secara individual (17\%). Metode ini akan mendukung kompetensi mahasiswa dalam hal kepercayaan, keahlian komunikasi secara lisan dan tulisan, keahlian berinteraksi dengan kelompok, dan manfaat kognitif lainnya seperti: pemecahan masalah, pertimbangan, pengakuan adanya perbedaan, pemahaman terhadap masalah kontekstual, dan pemahaman materi yang lebih komprehensif (Richio and Sakata, 2000).

Penelitian Adel et al. (2003) menyimpulkan sebagian besar mahasiswa akuntansi memiliki gaya belajar converger. Hasil penelitian tersebut menunjukkan, sebagian besar mahasiswa akuntansi memiliki gaya belajar converger, yakni gaya belajar dimana cara memperoleh dengan cara memikirkannya (Abstract Conceptualization/AC) serta memproses informasi yang diperoleh dengan cara mempraktikannya (active 
experimentation/AE). Terdapat kesamaan hasil gaya belajar Dosen Akuntansi dengan Mahasiswa Akuntansi dalam hal pemrosesan informasi yaitu AE, tetapi berbeda dalam cara memperoleh informasi. Dosen akuntansi lebih cenderung berdasarkan pengalaman CE, sementara Mahasiswa Akuntansi cenderung berdasarkan konsep atau AC. Perbedaan ini dapat dijelaskan dengan logika bahwa Dosen Akuntansi memiliki riwayat pengetahuan yang lebih dibandingkan mahasiswa. Pengetahuan Dosen Akuntansi terkonstruksi sejak menempuh pendidikan akuntansi sampai dengan pada saat praktik mengajar. Sementara itu, pengetahuan Mahasiswa Akuntansi baru terkonstruksi ketika menempuh pendidikan akuntansi, sehingga sangat wajar bahwa perolehan informasi mereka sebatas pada konsep.

Kesamaan kecenderungan Dosen dan Mahasiswa Akuntansi dalam hal pemorosesan informasi yaitu akif bereksperimen atau berlatih atau $\mathrm{AE}$, menjadi temuan yang menarik. Bahwa kesamaan preferensi gaya belajar ini akan mempengaruhi hasil belajar mahasiswa. Hal ini bisa disimpulkan, sebagai contoh bahwa penugasan berupa latihan soal dan penyelesaian kasus yang dilaksanakan dengan baik oleh mahasiswa, tentunya akan mendukung hasil belajar mahasiswa. Hasil penelitian mengindikasikan bahwa kebiasaan bekerja mahasiswa seperti menyelesaikan tugas berhubungan dengan keberhasilan mahasiswa (Fad and Ryser, 1993).

Berdasarkan hasil penelitian ini, gaya belajar dosen akuntansi adalah accomodator. Dosen Akuntansi bergaya accommodator mengonfirmasi hasil penelitian Pujiningsih (2010), yang menyimpulkan mahasiswa S1 Pendidikan Akuntansi bergaya accommodator. Hasil ini berbeda dengan mahasiswa S1 Non Pendidikan dan D-3 Akuntansi yang masing-masing bergaya diverger dan assimilator (Pujiningsih, 2010). Dari hasil ini dapat diduga bahwa mahasiswa S1 Pendidikan Akuntansi berpotensi mendapatkan hasil belajar yang lebih baik, karena memiliki kesamaan gaya belajar dengan Dosen Akuntansi. Hal ini mendasarkan hasil penelitian Geiger and Boyle (1992), gaya belajar mahasiswa yang mirip dosen cenderung memiliki kinerja yang lebih baik.

\section{Metode Mengajar}

Dalam hal pengelolaan kelas dosen akuntansi dapat dikatakan cukup baik, hal ini dapat dilihat dari penekanan disiplin dan tata tertib kepada mahasiswa, memberikan reward bagi mahasiswa yang aktif selama perkuliahan, dan menghargai masukan yang 
diberikan oleh mahasiswa, dengan rata rata nilai di atas 4. Hal yang masih kurang dalam hal ini adalah perhatian dosen kepada mahasiswa yang kurang respon terhadap perkuliahan yang mendapatkan skor rata-rata 3,63. Hal tersebut dapat dijelaskan di sini, bahwa terdapat dua responden yang tidak setuju dengan perhatian dosen terhadap bagaimana cara belajar mahasiswa serta perhatian khusus terhadap mahasiswa yang kurang respon terhadap proses pembelajaran. Dengan demikian, dua hal tersebut perlu mendapatkan perhatian serta perlu peningkatan kinerja dosen dalam hal pengelolaan kelas. Oleh karena, salah satu ukuran efektifitas pembelajarann yang dilakukan dosen adalah kemampuan mereka dalam mengelola kelas. Salah satu indikator pengelolaan kelas yang baik adalah mahasiswa merasa terlibat dan bertanggung jawab dalam proses pembelajaran.

Metode pengajaran tradisional yang berupa ceramah masih menduduki peringkat teratas dalam metode pengajaran yang diterapkan oleh Dosen Akuntansi yakni sebesar $20 \%$. Peringkat kedua adalah metode dengan cara pemberian tugas rumah individu sebesar $17 \%$. Penelitian dan dan kunjungan ke perusahaan masih sedikit dilakukan yakni hanya sebesar $6 \%$ dan $7 \%$. Observasi ke perusahaan bisa dimasukkan dalam pendekatan contextual teaching and laerning (CTL). Dengan pendekatan ini diharapkan mahasiswa mendapatkan pengalaman belajar yang lebih bermakna berdasarkan pada masalah-masalah kontekstual di bidang akuntansi. CTL mampu mengasah intellectual skill. Intellectual skill diantaranya kemampuan mahasiswa mengidentifikasi sumber informasi akuntansi yang relevan (Bakker, et al.,1995).

Kuliah dalam bentuk seminar masih sedikit digunakan, hanya sebanyak $2 \%$. Kuliah dalam bentuk seminar sebenarnya dapat digunakan sebagai pelatihan mahasiswa dalam berfikir secara prosedural, yang mampu mengasah keterampilan dalam berargumentasi secara tertulis maupun lisan. Hal ini kemungkinan terjadi dikarenakan, hanya matakuliah tertentu saja yang dapat dilakukan dengan metode seminar. Sebagai contoh antara lain matakuliah Metodologi Penelitian, Seminar Akuntansi, dan Teori Akuntansi. Model seminar akan mempertajam kemampuan mahasiswa dalam menstruktur solusi masalah serta kemampuan berkomunikasi secara tertulis (Bakker, et al.,1995). Selain itu, metode seminar akan meningkatkan percaya diri, kemampuan berkomunikasi, berfikir kritis, dan berinteraksi interpersonal (Richio and Sakata, 2000). 
Ditinjau dari motivasi dosen Akuntansi dalam memperbarui metode pengajarannnya, sebanyak $41 \%$ dosen akuntansi ingin mengubah metode pengajaran yang selama ini mereka gunakan, tetapi yang menjadi kendala adalah tidak punya waktu yang cukup untuk mengubahnya. Hanya sebagian kecil dosen, yakni 3 orang dosen yang tidak ingin mengubah metode pengajarannya. Selain itu, sebanyak $41 \%$ dosen berpendapat bahwa selalu mengadakan perubahan yang disesuaikan materi, kondisi kelas serta hasil evaluasi proses pembelajaran. Dengan demikian dapat disimpulkan bahwa secara rata- rata dosen Akuntansi memiliki motivasi untuk melakukan inovasi metode pembelajaran.

\section{SIMPULAN}

Hasil penelitian menyimpulkan bahwa Dosen Akuntansi, dalam mendapatkan informasi lebih menyukai berdasarkan pengalaman atau concentrate experience $(C E)$. Sementara dalam hal memproses informasi yang telah diterimanya, sebagian besar Dosen Akuntansi lebih menyukai cara belajar dengan active experimentation $(A E)$. Perpaduan $C E$ dan $A E$ membentuk preferensi gaya belajar accomodator. Meskipun metode ceramah menempati nilai persentase urutan tertinggi dalam metode mengajar, tetapi metode pemberian tugas baik tugas individu dan tugas kelompok yang dilaksanakan dalam baik di luar maupun di dalam kelas, serta penyelesaian kasus dengan nilai persentase berada dibawah ceramah. Hal ini mengindikasikan bahwa banyaknya penugasan kepada mahasiswa mengindikasikan gaya belajar dosen yang accommodator, terutama merefleksikan active experimentation $(A E)$.

Berdasarkan pada hasil penelitian dapat disarankan hal-hal sebagai berikut: (1) untuk penelitian selanjutnya menarik untuk dikaji mengenai hubungan gaya belajar mahasiswa akuntansi dan gaya belajar dosen akuntansi terhadap hasil belajar mahasiswa; (2) Ruang penelitian selanjutnya yang memungkinkan untuk dikaji adalah hubungan antara gaya mengajar dosen dan metode mengajar dosen akuntansi terhadap hasil belajar mahasiswa akuntansi.

\section{DAFTAR RUJUKAN}


Adel at.al. 2003. An Investigation into preferred Learnig Styles of Accounting, Management, Marketing, and General Business Majors, Teaching \& Learning, 18 (1): 24-31.

Anderson, J.R., 1985, Language, Memory ang Thougth, Hilsade, NJ, Erlabum

Baker, R. , B. Cunningham; P. Kimmel; C. Vanable, A Catalog of Resource,1995. Materials for Teaching Accounting Students Critical Thinking, Accounting Pedagogical Ressource Series, vol 1. St Louis: Federation of Schools of Accountancy.

Dwiyogo, D. Wasis, 2004. Penelitian Tindakan Kelas (PTK). Makalah, Disampaikan pada Pelatiahan AA dan Pembuatan Buku Ajar, Universitas Negeri Malang

Duff, A.. 1995.The Impact of Learning Strategies on Accademic Performance in Accounting Undergraduater course, British accounting Association BAA-SIG, Dicussion Paper, No 8 October.

Fad,K.S, and G.R.Ryser, (1993) Social Behavior Related to Success in General Education. Remidial and Special Education 14(1):25-35

Gaiger and Boyle,1992. Learning Style of Student and Instructor: an Analysis of Course Performance and Satisfaction. The Accounting Education Journal.

Indriantoro,N. dan B. Supomo.1999. Metodologi Penelitian Bisnis. BPFE: Yogyakarta

Kolb. D. A. 1985. Learning Style Inventory Self Scoring Inventory and Interpretation Buuklt. Boston, NA: MCBER and Company.

Pujiningsih, S. 2010.Preferensi Gaya Belajar Mahasiswa Akuntansi. Jurnal Akuntansi El Muhasaba, 1(2):10-112.

Richio,E. and Sakata, M.C.G, 2000, Accounting Research in Brazilian Universities. 
